\title{
OBŁAWA AUGUSTOWSKA JAKO NAJWIEZKSZA NIEROZLICZONA ZBRODNIA DOKONANA NA POLAKACH PO II WOJNIE ŚWIATOWEJ
}

Streszczenie. Artykuł opisuje obławę augustowską, czyli największą zbrodnię na Polakach po II wojnie światowej, dokonaną w lipcu 1945 r. na ziemiach Suwalszczyzny i Augustowszczyzny, w wyniku której zginęło prawie 600 osób, głównie ludności cywilnej. Celem pracy była analiza przeszkód natury prawnej i praktycznej w dążeniu strony polskiej do rozliczenia zbrodni tzw. obławy augustowskiej. Z kolei problemem badawczym była odpowiedź na pytanie czy istnieją realne szanse uzyskania zadośćuczynienia od strony rosyjskiej za wydarzenia tzw. obławy augustowskiej na drodze krajowych i międzynarodowych procedur sądowych. Autor przedstawił genezę, przebieg i skutki przeprowadzenia obławy. Następnie podjęto próbę kwalifikacji prawnej tej zbrodni, a także przedstawiono aktualny stan śledztwa.

Słowa kluczowe: Augustów, Obława, Lipiec 1945 r., Mały Katyń.

\section{Wstęp}

W historii Polski na przestrzeni wieków miało miejsce wiele tragicznych wydarzeń. Okres zaborów czy II wojny światowej to tylko główne z najważniejszych przykładów bolesnych doświadczeń naszego narodu. Warto jednak podkreślić, iż podobne tragedie dotykały również mniejsze społeczności lokalne. Jednym z takich wydarzeń była obława augustowska, przeprowadzona latem 1945 r., za akceptacją najwyższych władz Związku Socjalistycznych Republik Radzieckich, na czele z Józefem Stalinem. Oddziały Armii Czerwonej przy pomocy żołnierzy Wojska Polskiego oraz funkcjonariuszy Urzędu Bezpieczeństwa przeprowadziły na terenach 
Puszczy Augustowskiej akcję pacyfikacyjną na bardzo dużą skalę. Po dokładnym przeszukaniu lasów i okolicznych wsi aresztowano kilka tysięcy osób, które podejrzewano o współpracę w polskim podziemiem niepodległościowym, w tym wiele kobiet i dzieci. Około sześciuset z zatrzymanych zaginęło bez śladu, co po upływie 73 lat można uznać za pewne, że zostali oni zamordowani na mocy tej samej decyzji, a miejsce ich pochówku pozostaje nieznane.

Celem niniejszego tekstu jest przedstawienie genezy, przebiegu i skutków przeprowadzenia obławy wraz z próbą dokonania odpowiedniej kwalifikacji prawnej tej zbrodni. Pozwoli to na analizę przeszkód jakie spotyka strona polska w dążeniu do rozliczenia obławy. Autor zdecydował się na wybór poniższej tematyki ze względu na fakt, że przebieg tamtych wydarzeń przez wiele lat był znany wśród wąskiej grupy osób, nie zaś wśród obywateli $\mathrm{z}$ całego kraju.

Źródłami wykorzystanymi w tekście były w głównej mierze publikacje pochodzące z Białostockiego Oddziału Instytutu Pamięci Narodowej wraz $\mathrm{z}$ oficjalnymi dokumentami dostępnymi w elektronicznym archiwum tejże placówki. Równie pomocne okazały się akty prawne z zakresu międzynarodowego prawa humanitarnego konfliktów zbrojnych, Internet zaś służył do pozyskania najnowszych informacji.

\section{Geneza przeprowadzenia obławy augustowskiej}

Na mocy ustaleń paktu Ribbentrop-Mołotow granica rozbiorowa pomiędzy III Rzeszą a Związkiem Radzieckim przebiegała bezpośrednio przez ziemie Suwalszczyzny. Cały powiat suwalski wraz z północnymi obszarami powiatu augustowskiego przyłączono ostatecznie do Prus Wschodnich, pozostała część powiatu, położona na południowy wschód od rzeki Blizny, stała się częścią Białoruskiej Socjalistycznej Republiki Radzieckiej. Po ataku III Rzeszy na Związek Radziecki ziemie polskie znalazły się w całości pod niemiecką okupacją, której towarzyszyło nasilenie represji, zwłaszcza wobec ludności żydowskiej, a także komunistów i inteligencji. Radziecka okupacja wróciła na Suwalszczyznę latem 1944 r., na skutek ofensywy Armii Czerwonej w ramach operacji o kryptonimie „Bagration”. Bliskie sąsiedztwo frontu utrzymało się jeszcze przez pół roku, kiedy to oddziały radzieckie ruszyły w kierunku Berlina. Na mocy ustaleń Wielkiej Trójki na konferencji w Jałcie w lutym 1945 r. Polska miała utracić Kresy Wschodnie na rzecz Związku Radzieckiego. Niektóre ze wsi dzisiejszego powiatu augustowskiego znajdowały się poza polskimi granicami aż przeprowadzenia korekty granic w kwietniu $1948 \mathrm{r}^{1}$

${ }^{1}$ J. Pawluczyk, Cierniowa droga do wolności. Wspomnienia żołnierza AK z okresu okupacji niemieckiej, sowieckiej i z czasów PRL-u, Białystok 2005, s. 13. 
Pierwsze oddziały partyzanckie na terenach powiatu suwalskiego i augustowskiego sformowano już jesienią 1939 r. Wśród głównych organizacji walczących na terenie Suwalszczyzny należy wymienić: Tymczasową Radę Ziemi Suwalskiej, Legię Piłsudskiego, Legion Ziemi Nadniemeńskiej czy Korpus Ziemi Suwalskiej. Wymienione ugrupowania realizowały zadania głównie o charakterze organizacyjnym, propagandowym i wywiadowczym. Akcje o charakterze zbrojno-dywersyjnym były rzadkością․ Okręg augustowski przejawiał o wiele większą aktywność zbrojną, którą wymierzono przede wszystkim w aktywistów radzieckich i osoby współpracujące z NKWD, gdyż wstępne szacunki wskazują zabicie przynajmniej 20 osób ${ }^{3}$. Dużą aktywnością wyróżniały się: Polska Armia Wyzwolenia, Związek Wolnej Polski oraz Dywersyjna Organizacja Wojskowa ${ }^{4}$.

Wojska wewnętrzne NKWD wraz z oddziałami liniowymi Armii Czerwonej starały się przeciwdziałać ruchom partyzanckim. Większość podejmowanych akcji kończyła się potyczkami. Ówczesny I sekretarz Komitetu Rejonowago Kp(b)B w Augustowie Nikołaj Awchimowicz w swoich wspomnieniach zwracał uwagę na szkodliwy charakter działalności kilkudziesięciu band, nazywając walki z nimi „ustawiczną wojną”. Wybuch wojny niemiecko-radzieckiej umożliwił utworzenie jednolitych struktur organizacji podziemnych zrzeszonych w ramach ZWZ. W połowie $1943 \mathrm{r}$. na Obwód Suwalski składało się 21 placówek zorganizowanych w 5 rejonów, zaś Obwód Augustowski tworzyło 12 placówek zorganizowanych w 4 rejony. Zgodnie z terminologią wojskową, która została przyjęta wiosną $1944 \mathrm{r}$, rejony były odpowiednikami batalionów, z kolei placówki - kompanii. Stan osobowy Inspektoratu Suwalskiego końcem czerwca 1944 r. wynosił 4976 żołnierzy ${ }^{6}$. Ich początkowa działalność opierała się na zadaniach organizacyjnych, jednak wraz z upływem czasu podejmowano się akcji sabotażowych, podczas których likwidowano agentów i rozbrajano posterunki żandarmerii ${ }^{7}$.

Na przełomie kwietnia i maja 1944 r. na terenach Puszczy Augustowskiej działalność rozpoczęła radziecka grupa desantowa NKGB, o charakterze

${ }^{2}$ P. Łapiński, Podziemie niepodległościowe $w$ pow. suwalskim i augustowskim $w$ latach 1939-1944, [w:] Obława augustowska (lipiec 1945 r.), red. J.J. Milewski, A. Pyżewska, Białystok 2005, s. 14

3 Ibidem, s. 15.

4 T. Strzembosz, Konspiracja na ziemi augustowskiej pod okupacją radzieckq (1939-1941), „Przegląd Historyczny” 1992, z. 4, s. 667-705.

${ }^{5}$ N. Awchimowicz, Mój Augustów, [w:] Europa nieprowincjonalna. Przemiany na ziemiach wschodnich dawnej Rzeczypospolitej (Białoruś, Litwa, Łotwa, Ukraina, wschodnie pogranicze III Rzeczypospolitej Polskiej) w latach 1772-1999, red. K. Jasiewicz, Warszawa 1999, s. 692-695.

${ }^{6}$ P. Łapiński, op. cit., s. 18-19.

7 Ibidem. 
dywersyjno-rozpoznawczym pod dowództwem majora Konstantego Cwietyńskiego „Orłowa”. Nawiązanie współpracy z lokalnym oddziałem AK nastąpiło niezwłocznie, czego przykładem mogą być udane zasadzki dokonane na wycofujących się niemieckich oddziałach na trasie Augustów - Grodno. Po wkroczeniu Armii Czerwonej przystąpiono z kolei do rozbrajania i internowania polskich oddziałów. Żołnierze, którym udało się uniknąć aresztowań, powrócili do konspiracji. Dzięki działalności grupy „Orłowa” dysponowano dokładnymi spisami partyzantów, dowódców rezerw oraz ludności cywilnej współpracującej z $\mathrm{AK}^{8}$.

Wraz z początkiem ofensywy Armii Czerwonej zimą 1945 r., przystąpiono do odbudowy oddziałów w obwodach augustowskim i suwalskim. Wobec mocno okrojonego składu struktur terenowych, przedsięwzięcia zbrojne ograniczały się do samoobrony i zapewnienia bezpieczeństwa osobom poszukiwanym przez służby. W kwietniu 1945 r. władze utraciły faktyczną kontrolę nad powiatem augustowskim. Większość urzędów gminnych przestała działać, a wielu funkcjonariuszy Milicji Obywatelskiej decydowało się na dezercję . Podobna sytuacja miała miejsce w powiecie suwalskim, gdzie spośród 14 gmin normalnie funkcjonowały tylko dwie. Komuniści zachowali faktyczną władzę w samych ośrodkach miejskich: Augustowie i Suwałkach. Podczas jednego z wieców jeden z majorów NKWD użył następujących słów:

Nie podoba się wam sukinsyny rząd lubelski, wy wszyscy jesteście bandytami z AK. Jeżeli was nie uspokoi wojsko polskie sprowadzimy 18 milionową armię sowiecką, która was nauczy rozumu i zaprowadzi tu porządek ${ }^{10}$.

Decyzja o ostatecznej likwidacji oddziałów konspiracyjnych na terenach powiatu augustowskiego i suwalskiego w ramach jednej, zorganizowanej akcji, zapadła najprawdopodobniej 16 maja $1945 \mathrm{r}$. w Białymstoku podczas narady z udziałem władz wojewódzkich i wojsk wewnętrznych NKWD ${ }^{11}$. Liczebność radzieckich oddziałów zaczęła gwałtownie rosnąć, a już 20 maja doszło do pierwszej łapanki, podczas odpustu we wsi Studzieniczna. Do aresztowań doszło także w Augustowie, Gorczycy, Suchej Rzeczce i Płaskiej. Zatrzymaniom towarzyszyły przypadki zabójstw, rabunków i gwałtów. Wszelkie skargi ludności cywilnej były niezwłocznie odrzucane, co dopro-

${ }^{8}$ K. Krajewski, T. Łabuszewski, Białostocki Okręg AK-AKO: VII 1944 - VIII 1945, Warszawa 1997, s. 428.

${ }^{9}$ D. Kaszlej, Z. Kaszlej, Zbrojne podziemie niepodległościowe na Suwalszczyźnie i Augustowszczyźnie od jesieni 1944 r. do jesieni 1954 r., [w:] Obława augustowska (lipiec 1945 r.), red. J.J. Milewski, A. Pyżewska, Białystok 2005, s. 31.

${ }^{10}$ J. Szlaszyński, Dzieje lipcowej obławy 1945 r., „Przegląd Augustowski” 1996, nr 5, s. 9.

11 D. Kaszlej, Z. Kaszlej, op. cit., s. 33. 
wadziło do nasilenia ataków na żołnierzy radzieckich oraz ignorowania zarządzeń władz lokalnych ${ }^{12}$.

Władze radzieckie zdecydowały o użyciu do pacyfikacji Puszczy Augustowskiej wojsk powracających do kraju z obszaru Prus Wschodnich, a Sztab Generalny opracował plan zgodnie z wytycznymi Stalina. Władze polskie mogły wysunąć taki pomysł jako pierwsze podczas posiedzenia Wojewódzkiego Komitetu Politycznego do Spraw Zwalczania Bandytyzmu w Białymstoku, które odbyło się 30 czerwca 1945 r. Wszelkie oficjalne decyzje do przeprowadzenia obławy zostały podjęte ${ }^{13}$, a kilkumiesięczne przygotowania pozwalają stwierdzić, że nie miała ona przypadkowego charakteru, będąc zaplanowana w dość szczegółowy sposób.

\section{Przebieg i skutki obławy augustowskiej}

Obława augustowska, zwana także lipcową lub suwalską objęła swym zasięgiem tereny powiatów: augustowskiego, suwalskiego oraz część sokólskiego, a także obszary przygraniczne na terenie Litwy. Najczęściej występującymi datami granicznymi jej przeprowadzenia są: 12-18 lipiec, 11-24 lipiec lub 10-25 lipiec $1945 \mathrm{r}$. Oficjalnym dokumentem potwierdzającym rozpoczęcie obławy jest datowany na 12 lipca telefonogram majora Wasilenki, w którym informuje on Wojewódzki Urząd Bezpieczeństwa Publicznego w Białymstoku o podjęciu operacji przeczesywania terytorium powiatu suwalskiego, która będzie kontynuowana mniej więcej 4-5 dni tj. do jej zakończenia ${ }^{14}$. Autor wspomina także o przybyciu kompanii Wojska Polskiego z dywizji im. Tadeusza Kościuszki, najprawdopodobniej kompanii z 1. Pułku Praskiego $^{15}$. Innymi formacjami wojskowymi, które brały udział w obławie były regularne jednostki armii radzieckiej ze składu 1 Frontu Białoruskiego oraz 62 Dywizji Strzeleckiej Wojsk Wewnętrznych NKWD. Na terenach objętych obławą działał także 385 pułk piechoty Wojsk Wewnętrznych NKWD, będący częścią tej Dywizji ${ }^{16}$.

12 Brudnopis meldunku sytuacyjnego przewodnika wywiadu Obwodu AKO Augustów za czerwiec 1945 r., część II (fragment), [w:] Obława Augustowska - lipiec 1945 r. Wybór źródeł, red J.J. Milewski, A. Pyżewska, Białystok 2010, s. 51.

${ }_{13}$ J. Szlaszyński, A. Makowski, Augustów. Monografia historyczna, Augustów 2007, s. 619.

14 Telefonogram kierownictwa PUBP $w$ Suwałkach do WUBP $w$ Białymstoku informujacy o rozpoczęciu operacji przeczesywania lasów, [w:] Obława Augustowska - lipiec 1945 r. Wybór źródet, red. J.J. Milewski, A. Pyżewska, Białystok 2010, s. 84.

${ }^{15}$ Ibidem.

${ }^{16}$ W. Roman, Działalność wojsk NKWD przeciwko polskiemu podziemiu w świetle dokumentów sowieckich, [w:] Zbrodnie NKWD na obszarze województw wschodnich Rzeczypospolitej Polskiej, red. B. Polak, Koszalin 1995, s. 205. 
Sztaby dysponowały dokładnymi wykazami zarejestrowanych członków AKO oraz cennymi dokumentami pochodzącymi z Urzędu Bezpieczeństwa, które zostały sporządzone i przetłumaczone przez kierownika PUBP w Augustowie Aleksandra Kuczyńskiego. Puszcza Augustowska i okoliczne miejscowości były regularnie przeszukiwane przez wojska radzieckie, którym towarzyszyli referenci UB. W pierwszych dniach aresztowano od kilku do kilkunastu osób dziennie, regularnie zwiększając liczbę zatrzymanych. Oprócz aresztowań dokonywano konfiskaty broni, głównie karabinów maszynowych i automatycznych. Ogrom działań przekraczał możliwości radzieckich śledczych, przez co z trudem udawało się przesłuchiwać zatrzymanych. Pierwsi z nich pod wpływem stosowanej przemocy wskazywali kolejnych potencjalnych podejrzanych. Polskie służby dokonywały samodzielnych akcji, a ich wykonawcy byli nagradzani pisemnymi pochwałami oraz pieniędzmi ${ }^{17}$.

Łącznie w trakcie obławy aresztowanych mogło zostać nawet około 7000 osób. Stan zakończenia procesów członków AK na dzień 26 lipca 1945 r. wynosił tylko 213 takich spraw, co może świadczyć o tym, że większość zatrzymań przeprowadzono bez posiadania dowodów na powiązanie aresztowanych $\mathrm{z}$ organizacjami partyzanckimi. Bezpośrednio po zatrzymaniu osadzeni trafiali tymczasowo do kilkunastu obozów filtracyjnych o bardzo prowizorycznym charakterze. Tworzono je w stodołach, świetlicach wiejskich czy przypadkowych domostwach. Tam odbywały się przesłuchania, którym towarzyszyły tortury i bicie. Do przykładowych metod zadawania bólu zaliczyć można polewanie zimną wodą, rażenie prądem czy sadzanie przesłuchiwanych na krzesłach z gwoździami, od których oczekiwano przyznania się do członkostwa w jakiejkolwiek organizacji niepodległościowej. Większość nie ukrywała swych związków z organizacjami zbrojnymi, zaznaczając przy tym, że miało to miejsce w latach 1941-1944, a więc podczas okupacji niemieckiej ${ }^{18}$.

Po pierwszej selekcji część z osadzonych odzyskiwała wolność, reszta trafiała do nowych miejsc odosobnienia. Przy pomocy kolejnych brutalnych przesłuchań dokonywano dalszego wyboru. Osoby, którym w znacznym stopniu udowodniono przynależność konspiracyjną, trafiały do trzeciego obozu filtracyjnego. Pozostali po maksymalnie kilkunastu dniach wracali do domów. Lokalizacja ostatniego obozu filtracyjnego, w przeciwieństwie do dwóch poprzednich, pozostawała tajemnicą. Rodziny nie mogły już dostar-

17 Archiwum IPN Białystok, 048/4/1, Rozkazy personalne KW MO za 1945 r. od nr 180 do nr 224, k. 53-54.

${ }_{18}$ M. Filipowicz, Obława augustowska w lipcu 1945 r., [w:] Obława augustowska (lipiec 1945 r.), red. J.J. Milewski, A. Pyżewska, Białystok 2005, s. 53. 
czać swoim bliskim żywności i odzieży, przed którymi była już tylko droga w nieznanym kierunku ${ }^{19}$.

W wyniku przeprowadzenia obławy augustowskiej zniszczeniu uległy siatki organizacyjne AK/AKO działające na ziemiach objętych pacyfikacją. Los około 600 osób pozostaje nieznany do dnia dzisiejszego ${ }^{20}$. Jest wielce prawdopodobne, że trafiły one na teren Związku Radzieckiego, gdzie poniosły śmierć w bliżej nieokreślonych okolicznościach. Istnieją przesłanki, by twierdzić, że akcja nie miała charakteru spontanicznego, tylko została przygotowana z zachowaniem najwyższej precyzji i staranności ${ }^{21}$. Nie bez znaczenia pozostaje fakt udziału strony polskiej przy przeprowadzeniu czystki. Jako przykład można podać postać generała Mirosława Milewskiego, późniejszego ministra spraw wewnętrznych i bliskiego współpracownika generała Wojciecha Jaruzelskiego. Podczas obławy miał zaledwie 17 lat, a jego czynne uczestnictwo w tamtych wydarzeniach potwierdzają zeznania świadków i fotografie. Na najbardziej znanej z nich Milewskiemu towarzyszą zaangażowani w obławę major Wasilenko czy szef PUBP w Augustowie Aleksander Kuczyński ${ }^{22}$. Z kolei świadkowie twierdzą, że generał wskazywał miejsca ukrycia lub zamieszkania konkretnych poszukiwanych osób, w tym swoich bliskich znajomych. Uczestniczył także w przesłuchaniach ofiar, czemu jednak później zaprzeczał ${ }^{23}$.

Obława augustowska to największa zbrodnia dokonana na ziemiach polskich po zakończeniu II wojny światowej. Bardzo często porównuje się ją do zbrodni katyńskiej. Z niektórych względów można ją nawet uznać za bardziej tragiczną, gdyż dotknęła w znacznej mierze ludność cywilną, a jej ofiarami było 27 kobiet i około 15 osób niepełnoletnich. Niektóre z zamordowanych kobiet były w ciąży, inne osierociły kilkumiesięczne dzieci. Szczególnie dotknięte zostały rodziny, spośród których zginęło po kilku ich członków²4.

19 Ibidem.

20 Vide: Obława augustowska (lipiec 1945 r.), red. J.J. Milewski, A. Pyżewska, Białystok 2005, s. 111; J. Schabieński, Gdzie sq nasi bliscy? Obława augustowska i jej konsekwencje, „Biuletyn Informacyjny" [miesięcznik Światowego Związku Żołnierzy Armii Krajowej] 2013, r. 23, nr 6 (278), s. 48.

${ }^{21}$ W swoich wspomnieniach Józef Pawluczyk zwraca uwagę na szczegół w postaci przygotowanych list z nazwiskami osób, które weryfikowano na podstawie dokumentów tożsamości. Opisuje on dokładny wygląd notatników, zwracając uwagę na szczegół w postaci skórzanych opraw. Stwierdza tym samym, że rozkazy pochodzą z najwyższego szczebla. Jemu samemu udało się uniknąć śmierci, z racji posiadania dokumentów na fałszywe nazwisko. Szerzej o tym w książce J. Pawluczyk, Cierniowa droga do wolności. Wspomnienia żołnierza AK z okresu okupacji niemieckiej, sowieckiej i z czasów PRL-u, Polskie Towarzystwo Historyczne Oddział w Białymstoku, Białystok 2005, s. 110.

22 M. Dzierżanowski, A. Blinkiewicz, W służbie Moskwy, „Tygodnik Wprost” 2005, nr 28 (1180), s. 32-33.

23 Ibidem.

24 Przykładem może być rodzina Wysockich ze wsi Biała Woda. W obławie zginął ojciec i dwie córki w wieku 17 i 22 lat. Jest to rodzina obecnego prezesa Związku Pamięci Ofiar 


\section{Próba kwalifikacji prawnej}

Podstawową trudnością w przyjęciu odpowiedniej kwalifikacji prawnej w odniesieniu do obławy augustowskiej są różnice występujące w dokumentacjach strony polskiej i rosyjskiej. Szereg pism do dziś pozostaje w archiwach Kremla, a polscy śledczy mają do nich mocno utrudniony dostęp. Badacze zajmujący się obławą bardzo często odwołują się do zbrodni katyńskiej, znane są bowiem ofiary oraz strona odpowiedzialna za ich śmierć, z zasadniczą różnicą, że w przypadku poszkodowanych w lipcu 1945 r. nie jest znany mechanizm mordu oraz miejsce pochówku ofiar.

Opierając się na ramach czasowych, za podstawowe dokumenty normujące prawo międzynarodowe w momencie dokonania obławy należy uznać Regulamin dotyczący praw i zwyczajów wojny lądowej zawarty w IV konwencji haskiej z 18 października 1907 r. oraz Konwencję Genewską z 27 lipca 1929 r. dotyczącą traktowania jeńców wojennych. Z uwagi na obecność wśród ofiar członków organizacji zbrojnych, którzy planowali w dalszym ciągu prowadzić działania zaczepne, a także fakt, że morderstw dopuścili się żołnierze Armii Czerwonej, powoływanie się na powyższe akty prawne wydaje się w pełni uzasadnione.

Polskie kodeksy karne z lat 1932 (art. 5), 1969 (art. 114) oraz aktualnie obowiązujący z 1997 r. (art. 110 § 1) mówią o popełnianiu czynów zabronionych wobec obywateli polskich na terenie naszego kraju przez cudzoziemców. Poza tym zabójstwo dokonane na jeńcu wojennym lub osobie cywilnej było zabronione zarówno w ówcześnie obowiązującym polskim kodeksie karnym z 1932 r. (art. 225), ale także przez Kodeks Karny ZSRR z 1926 r. (art. 137). Tym samym spełniony jest wymóg podwójnej bezprawności, co biorąc pod uwagę artykuły $110 \S 1$ oraz $111 \S 1$ kodeksu karnego z 1997 r., stwarza polskiemu wymiarowi sprawiedliwości pole do ścigania sprawców przestępstw przeciwko interesom Polski lub jej obywatelom, nawet jeśli sprawca czynu jest cudzoziemcem, a swój czyn popełnił poza granicami Polski ${ }^{25}$.

Obecnie w śledztwie prowadzonym przez Oddziałową Komisję Ścigania Zbrodni Przeciwko Narodowi Polskiemu obława określana jest jako zbrodnia przeciwko ludzkości. Pojęcie to pojawiło się w podpisanym 8 sierpnia 1945 r. statucie Międzynarodowego Trybunału Wojskowego, a więc niedługo

Obławy Augustowskiej 1945 r. ks. prałata Stanisława Wysockiego. Więcej na stronie: www. naszdziennik.pl/mysl/57837,sladami-oblawy.html, dostęp: 11.09.2018.

${ }^{25}$ Przypuszcza się, że ofiary obławy augustowskiej zabito na terytorium Związku Radzieckiego, pomimo że zostały aresztowane i poddawane torturom na terenie Polski. Do samego aktu morderstwa doszło już jednak poza granicami naszego kraju w związku z czym przytoczenie powyższych artykułów może mieć miejsce, www.oblawaaugustowska.pl, dostęp: 11.09.2018. 
po zakończeniu pacyfikacji Puszczy Augustowskiej. Paradoksem jest fakt, że powyższego terminu jako pierwsi użyli oskarżyciele radzieccy, sami dopuszczając się czynów składających się na to pojęcie. Innego zdania jest rosyjskie stowarzyszenie „Memoriał” na czele z Nikitą Pietrowem, którego zdaniem obławę należy traktować w kategoriach zbrodni wojennej. Ze względu na brak całkowitego dostępu do archiwów nie jest aktualnie możliwe przyporządkowanie do jednego konkretnego rodzaju zbrodni będących złamaniem zasad prawa międzynarodowego.

Mianem zbrodni wojennej w ogólnej definicji określa się jakiekolwiek działania powodujące naruszenie praw i zwyczajów wojennych i powagę traktatów ${ }^{26}$. W 1945 r. Komisja Narodów Zjednoczonych do Spraw Zbrodni wojennych ustaliła zasady odpowiedzialności za popełnienie czynów rozumianych jako zbrodnie wojenne. Rozbudowaną definicję tego pojęcia zawarto w art. VIb Karty Międzynarodowego Trybunału Wojskowego. W jego brzmieniu zbrodnia wojenna jest pogwałceniem praw i zwyczajów wojennych, które nie ogranicza się do morderstw, ale także swoim zakresem obejmuje złe obchodzenie oraz deportację na roboty przymusowe bądź też w innych celach ludności na obszarze znajdującym się pod okupacją lub z tegoż obszaru. Ponadto dotyczy ono mordowania i złego traktowania jeńców wojennych lub osób na morzu, pozbawiania życia zakładników, rabowania własności publicznej lub prywatnej, burzenia budynków mieszkalnych, a także czynienia spustoszeń, które nie są usprawiedliwione koniecznością wynikającą z działań wojennych ${ }^{27}$.

Jako, że wśród ofiar obławy augustowskiej byli członkowie zbrojnych oddziałów partyzanckich, po zatrzymaniu powinien im przysługiwać status jeńców wojennych, pomimo, iż nie trafili do niewoli dobrowolnie, do końca walcząc z bronią $\mathrm{w}$ ręku, bądź też będąc aresztowanymi z zaskoczenia. Złe traktowanie przejawiało się $\mathrm{w}$ przetrzymywaniu $\mathrm{w}$ trudnych warunkach, jakie panowały w punktach filtracyjnych, na których potrzeby wykorzystywano piwnice, stajnie czy stodoły oraz stosowaniem wobec nich przemocy. Ponadto ludność cywilna wnosiła wiele skarg do władz lokalnych skarżąc się na kradzieże dokonywane przez Rosjan. Dotyczyły one nie tylko grabieży mienia w postaci kosztowności czy jedzenia, ale także niszczeniem plonów czy odbieraniem inwentarza rolnikom. Zgromadzenie Ogólne ONZ nakazało wprowadzenie treści całego artykułu VI do krajowych kodeksów karnych. Polska uczyniła to w $1947 \mathrm{r}$.

${ }^{26}$ Definicja ta wynika z artykułu 227 Traktatu Wersalskiego, którego treść dostępna jest na stronie internetowej: http://isap.sejm.gov.pl/DetailsServlet?id=WDU19200350200, dostęp: 11.09.2018.

27 Art. VIa Karty Międzynarodowego Trybunału Wojskowego z 8 sierpnia 1945 r. 
Znacznie bardziej rozbudowana jest definicja zawarta w Rzymskim Statucie Międzynarodowego Trybunału Karnego z dnia 17 lipca 1998 r. Otóż zbrodnia wojenna zgodnie z artykułem 8 punkt 2 jest poważnym naruszeniem Konwencji Genewskich z dnia 12 sierpnia 1949 r. rozumianym jako działanie wymierzone w ludzi bądź dobra chronione przez odpowiadającą im Konwencję Genewską. Za takie działania należy uważać między innymi:

- zamierzone zabójstwo;

- tortury bądź nieludzkie traktowanie, wliczając w to eksperymenty biologiczne;

- umyślne sprawianie cierpienia lub doprowadzenie do ciężkich uszkodzeń ciała i zdrowia;

- dokonywanie poważnych zniszczeń i przywłaszczanie mienia nieznajdujące usprawiedliwienia koniecznością działań wojennych, dokonane bezprawnie i samowolnie;

- umyślnie pozbawienie jeńców do rzetelnego procesu, który musi być prowadzony w normalnym trybie.

Do kategorii zbrodni wojennych zalicza się także atakowanie ludności cywilnej lub osób o takim charakterze niebiorącym udziału w działaniach wojennych ${ }^{28}$.

Nikita Pietrow uzasadniając swoją kwalifikację prawną dotyczącą obławy augustowskiej jako główny argument podaje mordowanie aresztowanych bez procesu i śledztwa, czego żadne prawa wojenne nie przewidują, a wręcz zakazują. Pozbawienie życia odbyło się zgodnie z wytycznymi i z niezwykłą skrupulatnością. Podkreśla, że po zakończeniu śledztwa katyńskiego Główna Prokuratura Wojskowa Federacji Rosyjskiej zajęła się głównie zacieraniem śladów i niszczeniem dowodów dotyczących zbrodni okresu stalinowskiego $^{29}$. 0 ile proces zbrodniarzy hitlerowskich rozpoczął się już rok po zakończeniu II wojny światowej, a największych z nich skazano na karę śmierci, to do dziś nie przedstawiono zarzutów ani jednej osobie związanej z obławą augustowską. Niekoniecznie należy przez to rozumieć żołnierzy sowieckich, ale chociażby funkcjonariuszy polskiego Urzędu Bezpieczeństwa, którzy wykazując się oddaniem w niesieniu pomocy czerwonoarmistom, przyczynili się do pozbawienia życia swoich rodaków, za co nie zostali nigdy ukarani, a wręcz przeciwnie nagrodzeni.

${ }^{28}$ Art. 6b Rzymskiego Statutu Międzynarodowego Trybunału Karnego (Dz.U. z 2003 r. $\mathrm{Nr} 78$, poz. 708). Tekst dostępny na stronie internetowej: http://prawo.sejm.gov.pl/isap. nsf/download.xsp/WDU20030780708/0/D20030708.pdf, dostęp: 11.09.2018.

${ }^{29}$ N. Pietrow, Psy Stalina, Warszawa 2012, s. 226. 
Oddziałowa Komisja Ścigania Zbrodni Przeciwko Narodowi Polskiemu kategoryzuje obławę augustowską jako zbrodnię przeciwko ludzkości. Zgodnie z artykułem VI punkt c. Karty Międzynarodowego Trybunału Wojskowego podpisanej 8 sierpnia 1945 r. w Londynie, zbrodniami przeciwko ludzkości są

Morderstwa, wytępianie, obracanie ludzi w niewolników, deportacja i inne czyny nieludzkie, których dopuszczono się przeciwko jakiejkolwiek ludności cywilnej, przed wojną lub podczas niej, albo prześladowania ze względów politycznych, rasowych lub religijnych przy popełnianiu jakiejkolwiek zbrodni wchodzącej w zakres kompetencji Trybunału lub w związku z nią, niezależnie od tego, czy było to zgodne, czy też stało w sprzeczności z prawem kraju, w którym zbrodni dokonano ${ }^{30}$.

Odpowiedzialność za popełnienie takiego czynu miała być osobista i podlegać jurysdykcji Trybunału. Jak już wspomniano wcześniej, zabójstwo podlegało karalności według polskiego kodeksu karnego z 1932 r. Obława augustowska nosiła także znamiona prześladowania ze względów politycznych, gdyż członków podziemia uważano za wrogów władzy i główne przeszkody do wprowadzania nowego ładu i porządku po zakończeniu II wojny światowej na terenie Polski. Ofiary przymusowo deportowano prawdopodobnie do Związku Radzieckiego, gdzie później poniosły śmierć. W latach powojennych pojęcie zbrodni przeciwko ludzkości nie było dobrze zdefiniowane. Łączono je i używano naprzemiennie z terminem ludobójstwa, które jest kwalifikowaną postacią zbrodni przeciwko ludzkości. Mimo tego nie zostało ono ujęte w deklaracji z Londynu.

Czyny dokonane w trakcie obławy augustowskiej niewątpliwie wpisują się $\mathrm{w}$ ramy przytoczonej definicji, jednak pojawiają się wątpliwości co do ich czasowego zastosowania. Rozwiązaniem było uchwalenie w Nowym Jorku Konwencji o niestosowaniu przedawnienia wobec zbrodni wojennych i zbrodni przeciw ludzkości 26 listopada 1968 r. Zgodnie z artykułem I zbrodnie zdefiniowane w Karcie Międzynarodowego Trybunału Wojskowego nie ulegają przedawnieniu niezależnie od daty ich dokonania. Ponadto postanowienia tej Konwencji zgodnie z artykułem II mają zastosowanie wobec zarówno władz państwowych, jak i osób prywatnych, biorących udział w popełnieniu danej zbrodni w roli sprawców, współuczestników albo bezpośrednio podżegających do ich dokonania ${ }^{31}$.

30 Art. VIc Karty Międzynarodowego Trybunału Wojskowego (Dz.U. z 1947 r. Nr 63, poz. 367), tekst dostępny na stronie internetowej: http://prawo.sejm.gov.pl/isap.nsf/download.xsp/WDU19470630367/0/D19470367.pdf, dostęp: 11.09.2018.

${ }^{31}$ Art. I i II Konwencji o niestosowaniu przedawnienia wobec zbrodni wojennych i zbrodni przeciw ludzkości (Dz.U. z 1970 r. Nr 26, poz. 208, załącznik i z 1971 r., nr 7, poz. 85). Tekst 
Według aktualnych przepisów prawa międzynarodowego za zbrodnie przeciwko ludzkości uznaje się rażące naruszenie jakiegokolwiek z punktów Karty Narodów ONZ. Poza tym w ich skład wchodzi dodatkowo kilka innych zbrodni, które dokładnie określono w Kodeksie Zbrodni przeciw Ludzkości, stanowiącego część Traktatu Rzymskiego, przyjętego 17 lipca 1998 r., pod którym podpisało się większość członków ONZ. Stanowi on podstawę funkcjonowania Międzynarodowego Trybunału Karnego z siedzibą w holenderskiej Hadze ${ }^{32}$. Zgodnie z artykułem 7 powyższego Traktatu zbrodnią przeciwko ludzkości jest jakikolwiek czyn, którego dokonano w ramach rozległego lub systematycznego, świadomego ataku skierowanego przeciwko ludności cywilnej. Do kategorii takich czynów należą ${ }^{33}$ :

- zabójstwo;

- eksterminacja;

- niewolnictwo;

- deportacja lub przymusowe przemieszczanie ludności;

- uwięzienie lub inne dotkliwe pozbawienie wolności fizycznej z naruszeniem podstawowych reguł prawa międzynarodowego;

- zgwałcenie, niewolnictwo seksualne, przymusowa prostytucja i sterylizacja;

- tortury;

- wymuszone zaginięcia osób;

- zbrodnia apartheidu;

- inne nieludzkie czyny o podobnym charakterze celowo sprawiające cierpienie lub poważne uszkodzenia ciała albo zdrowia psychicznego lub fizycznego.

W rozumieniu punktu 2 przytoczonego artykułu jako atak skierowany przeciwko ludności cywilnej należy uznać wielokrotne dopuszczanie się wyżej wymienionych czynów podjętych w celu wykonania założeń polityki państwowej bądź też organizacyjnej, która zorganizowała taki atak. Z kolei wymuszone zaginięcia osób charakteryzują się tym, że po dokonaniu

konwencji dostępny na stronie internetowej: http://prawo.sejm.gov.pl/isap.nsf/download. xsp/WDU19700260208/0/D19700208.pdf, dostęp: 11.09.2018.

${ }_{32}$ Art. 3 pkt. 1 Rzymskiego Statutu Międzynarodowego Trybunału Karnego (Dz.U. z 2003 r. $\mathrm{Nr} 78$, poz. 708), Tekst dostępny na stronie internetowej: http://prawo.sejm.gov.pl/isap.nsf/ download.xsp/WDU20030780708/0/D20030708.pdf, dostęp: 11.09.2018.

${ }^{33}$ Art. 7 Rzymskiego Statutu Międzynarodowego Trybunału Karnego (Dz.U. z 2003 r. Nr 78, poz. 708), Tekst dostępny na stronie internetowej: http://prawo.sejm.gov.pl/isap.nsf/download.xsp/WDU20030780708/0/D20030708.pdf, dostęp: 11.09.2018. 
zatrzymań strona dopuszczająca się tego czynu zaprzecza faktom ich zrealizowania oraz odmową udzielenia informacji o losie i miejscu pobytu osób zaginionych ${ }^{34}$.

Pogrubione punkty można przypisać wydarzeniom obławy augustowskiej. Mamy do czynienia z niewyjaśnionym zabójstwem prawie 600 osób, które uprzednio uwięziono i torturowano w trakcie przesłuchań z wyjątkowym okrucieństwem. Ponadto radzieccy żołnierze dopuszczali się gwałtów na kobietach, które nie były przewidziane do aresztowania. Należy jednak pamiętać, że Rosja w ogóle nie podpisała Traktatu Rzymskiego, w związku z czym trudno będzie wyegzekwować od niej odpowiedzialność za ten czyn. Ponadto Międzynarodowy Trybunał Karny w Hadze nie zajmuje się sądzeniem państw, posiada bowiem jedynie uprawnienia do wymierzania kar osobom fizycznym. Nazwiska sprawców możemy ewentualnie poznać w przyszłości, po ujawnieniu odpowiednich dokumentów przez Prokuraturę Generalną Federacji Rosyjskiej. Na ich ukaranie jest zdecydowanie za późno z bardzo prostych przyczyn - wszyscy lub zdecydowana większość osób odpowiedzialnych pośrednio lub bezpośrednio za przeprowadzenie obławy augustowskiej nie żyje. Sama strona rosyjska w decyzji z 1995 r. umarzającej śledztwo w sprawie obławy augustowskiej stwierdziła, że bezpośredni koordynatorzy czystek na Suwalszczyźnie nie żyją, co świadczy o tym, że nazwiska tych osób były znane, gdyż taki komunikat wystosowano dopiero rok po śmierci majora Gorgonowa. Pojęcie zbrodni komunistycznej pojawiło się w polskim prawie wraz z wejściem w życie Ustawy z dnia 18 grudnia $1998 \mathrm{r}$. o Instytucie Pamięci Narodowej - Komisji Ścigania Zbrodni przeciwko Narodowi Polskiemu. Zgodnie z art. $2 \S 1$ powyższej ustawy za zbrodnię komunistyczną uznaje się:

czyny popełnione przez funkcjonariuszy państwa komunistycznego w okresie od dnia 17 września 1939 r. do dnia 31 lipca 1990 r., polegające na stosowaniu represji lub innych form naruszania praw człowieka wobec jednostek lub grup ludności bądź w związku z ich stosowaniem, stanowiące przestępstwa według polskiej ustawy karnej obowiązującej w czasie ich popełnienia [... ${ }^{35}$.

${ }^{34}$ Rosjanie przez dłuższy czas utrzymywali, że nie posiadają wiedzy na temat wydarzeń z lipca 1945 r. Podobny mechanizm działał w przypadku zbrodni katyńskiej, gdzie w pewnym momencie wykorzystano wersję, jakoby kilkudziesięciotysięczna grupa oficerów Wojska Polskiego udała się do Mandżurii i tam słuch po nich zaginął.

${ }^{35}$ Art. 2 § 1 Ustawy z dnia 18 grudnia 1998 roku o Instytucie Pamięci Narodowej - Komisji Ścigania Zbrodni przeciwko Narodowi Polskiemu (Dz.U. z 1998 r. Nr 155, poz. 1016). Ustawa dostępna na stronie: http://prawo.sejm.gov.pl/isap.nsf/download.xsp/ WDU19981551016/0/D19981016.pdf, dostęp: 11.09.2018. 
Cytowany artykuł wskazuje także, że funkcjonariuszem państwa komunistycznego:

jest funkcjonariusz publiczny, a także osoba, która podlegała ochronie równej ochronie funkcjonariusza publicznego, w szczególności funkcjonariusz państwowy oraz osoba pełniąca funkcję kierowniczą w organie statutowym partii komunistycznych ${ }^{36}$.

Tym samym pojawia się trudność w udowodnieniu potencjalnej winy funkcjonariuszom wywodzącym się z innego kraju o ustroju komunistycznym, konkretnie Rosji. Nie ma bowiem żadnych bezpośrednich odniesień do obywateli państw obcych. Rozstrzygnięcie tej kwestii było jednym z pierwszych konfliktów interpretacyjnych w dochodzeniu w sprawie obławy augustowskiej, który znalazł swoje rozwiązanie w drodze przeprowadzonej wykładni prawa. Zarówno obecny kodeks karny, jak i ten obowiązujący w czasie przeprowadzenia pacyfikacji odpowiednio w artykułach 5 i 3 wskazuje, że odpowiedzialność ponosi każdy, kto dopuścił się popełnienia przestępstwa na obszarze Polski. Oczywiście występują tu także wyjątki wynikające z podpisanych umów międzynarodowych, które wyłączają określone kręgi osób, głównie dyplomatów. Poza tym opisywana kategoria przestępstw nie określa zbrodni wojennych, zbrodni przeciwko ludzkości, które zaliczają się do szczególnych rodzajów czynów objętych karą, gdyż normują je traktaty i umowy międzynarodowe. W związku z czym odpowiedzialność ogranicza się do zasad ogólnych ${ }^{37}$.

Taki stan rzeczy uległ zmianie dopiero po wprowadzeniu ustawy o Instytucie Pamięci Narodowej, która to precyzuje definicje zbrodni komunistycznej. Odpowiedzialność za nią nie sprowadza się do kryterium narodowości sprawcy. W związku z tym, podstawowym warunkiem ponoszenia odpowiedzialności przez funkcjonariusza komunistycznego jest wyczerpanie dyspozycji wyrażonych w art. $2 \S 1$. Zabójstwa osób cywilnych z racji ich wrogiego stosunku do ustroju komunistycznego i Rosji sowieckiej, należy jednoznacznie określić mianem zbrodni komunistycznejej ${ }^{38}$. Należy jednak pamiętać, że za potencjalnych sprawców obławy augustowskiej należy również uznać obywateli polskich, których odpowiedzialność nie może być w jakimkolwiek stopniu umniejszana. Zeznania rodzin poszkodowanych w zdecydowanej większości sugerują, że ich bliscy byli aresztowani przez Sowietów.

${ }^{36}$ Art. 2 § 2 Ustawy z dnia 18 grudnia 1998 roku o Instytucie....

${ }^{37}$ T. Kamiński, Specyfika postępowań karnych dotyczacych zbrodni komunistycznych - wybrane zagadnienia na przykładzie śledztwa w sprawie tzw. „obławy augustowskiej”, [w:] Obława augustowska (lipiec 1945 r.), red. J.J. Milewski, A. Pyżewska, Białystok 2005, s. 89-91.

${ }^{38}$ Ibidem. 
Warto podkreślić, że uczestnictwo polskich służb jest udowodnione, gdyż ich funkcjonariusze byli rozpoznawani przez świadków. Poza tym niektóre pisma potwierdzają także udział członków lokalnych struktur Polskiej Partii Robotniczej. Nie były one jednak do końca informowane o szczegółach prowadzenia akcji, pozostając bez znaczącego wpływu na poczynania sowieckich dowódców i doradców ${ }^{39}$.

Dokumenty autorstwa UB lub MO zostały w taki sposób sporządzone, aby w jak największym stopniu wykluczyć fakt popełniania czynów zabronionych. Większość raportów sugeruje, że ranny i bezbronny zatrzymany podejmował próbę ucieczki bądź obezwładnienia osoby zatrzymującej wraz z przejęciem jej broni. Takie pisma urzędowe nie są jednak do końca nieprzydatne, gdyż zawierają nazwiska potencjalnych sprawców z całym szeregiem dowódczym. Niestety, w znacznej mierze potwierdzają one tylko sam fakt przeprowadzenia czystki, brak jest natomiast jej szczegółowych opisów. Te istnieją głównie dzięki osobistym relacjom świadków tamtych zdarzeń, czyli rodzin ofiar, a także osób, które odzyskały wolność po wcześniejszym aresztowaniu.

Ustawa określa także, że jeśli popełnione zbrodnie komunistyczne są według prawa międzynarodowego zbrodniami przeciwko pokojowi, ludzkości lub zbrodniami wojennymi, nie ulegają wtedy przedawnieniu. $\mathrm{W}$ innym przypadku bieg terminu przedawnienia rozpoczyna się od dnia 1 sierpnia 1990 r. i wynosi 40 lat dla zbrodni zabójstwa, a także 30 lat, gdy czyn stanowi inną zbrodnię komunistyczną. Dla takich sprawców nie stosuje się przepisów prawnych określających amnestię, a wydanych przed dniem 7 grudnia $1989 \mathrm{r}^{40}$

Przeprowadzona analiza pokazuje, że obława augustowska była rażącym naruszeniem przepisów prawa międzynarodowego. Pojawiają się jednak trudności z jej odpowiednią kwalifikacją prawną. Poszczególne elementy popełnienia tej zbrodni przez Rosjan powodują, że część ekspertów przyporządkowuje jej znamiona zbrodni wojennej, z kolei inni traktują to jako zbrodnie przeciwko ludzkości. Konflikt powstaje z racji tego, że ofiarami byli zarówno członkowie organizacji zbrojnych, którzy nie prowadzili jednak regularnych działań militarnych, jak i ludność cywilna, która podejmowała próby powrotu do normalnego życia po zakończonej II wojnie światowej. Dodatkowo obławę można zaliczyć do kategorii zbrodni komunistycznej, z racji jej dokonania w danym okresie historycznym przez funkcjonariuszy państwa o takim właśnie ustroju.

39 Ibidem.

${ }^{40}$ Art. 4 ustawy z 18 grudnia 1998 roku o Instytucie... 
Jaką kolejną przeszkodę należy uznać fakt, że w lipcu 1945 r. nie istniała żadna instytucja zajmująca się karaniem sprawców zbrodni wojennych. Konwencje haskie i genewskie oraz inne porozumienia nie ustanowiły żadnego organu, który miałby jurysdykcję nad tą dziedziną prawa. Państwa uczestniczące w tych traktatach musiały na własną rękę karać sprawców wedle swoich przepisów prawa karnego. Międzynarodowy Trybunał Wojskowy w Norymberdze był pierwszą taką instytucją, jednak powstał on w celu przeprowadzenia procesu karnego w jednej konkretnej sprawie, jaką były zbrodnie hitlerowskie. Jednak dzięki Statutowi tego Trybunału powstały konwencje genewskie z 1949 r. wraz z protokołami dodatkowymi z $1977 \mathrm{r}$. Międzynarodowy Trybunał Karny w Hadze powołany do życia dopiero pod koniec ubiegłego wieku zajmuje się sądzeniem osób fizycznych, które dopuściły się naruszenia zapisów obowiązujących w tychże konwencjach. Nie ma niestety możliwości sądzenia państw jako podmiotów prawa międzynarodowego. Być może odpowiednia kwalifikacja prawna obławy augustowskiej byłaby możliwa po ujawnieniu przez stronę rosyjską wszystkich dokumentów mających jakikolwiek związek z tą sprawą, jednak brak jest w tej kwestii chęci do współpracy ze strony Kremla. Po 70 latach od dokonania tego mordu pewne jest, że sprawców nie uda się ukarać, można jedynie poznać ich nazwiska. Jest to konieczne, gdyż czyny zabronione jakich się dopuszczali nie są w jakikolwiek sposób wytłumaczalne i powinno się je piętnować. Dzisiaj rodziny pomordowanych skupiają się przede wszystkim na procesach rehabilitacji swoich bliskich i dokładnym poznaniu ich losu po aresztowaniu. 45 lat panowania ustroju komunistycznego w Polsce sprawiło, że likwidatorzy oddziałów partyzanckich nie zostali ukarani, a teraz pomimo, że tego rodzaju zbrodnie nie ulegają przedawnieniu, świat nie usłyszy wyroków w ich sprawie.

\section{Dążenia strony polskiej do wymierzenia odpowiedzialności za przeprowadzenie obławy}

Rodziny aresztowanych jeszcze w czasie trwania obławy udawały się do punktów filtracyjnych w celu dostarczenia bliskim ubrań i żywności, jednak z czasem tracili z nimi kontakt. Lokalna administracja nie była w stanie udzielić im odpowiedzi na pytania o los zaginionych. Padały groźby pozbawienia życia $\mathrm{w}$ razie prowadzenia dalszych poszukiwań ${ }^{41}$. Władze gminne prowadziły własne działania mające na celu wyjaśnienie losu ofiar. Najbardziej aktywna była gminy Giby, z terenów której pochodziło ponad 80 ofiar. Większość z nich była zwyczajnymi robotnikami i rolnikami, często jedy-

\footnotetext{
${ }^{41}$ I. Sewastianowicz, S. Kulikowski, Nie tylko Katyń, Białystok 1990, s. 27.
} 
nymi żywicielami rodzin. Pozostawiona przez nich ziemia stawała się nieużytkami, a ich rodziny znalazły się w bardzo trudnej sytuacji materialnej ${ }^{42}$.

Większość rodzin skupiała się również na samodzielnych poszukiwaniach, korespondując przede wszystkim z Polskim Czerwonym Krzyżem. Najczęstsza padająca odpowiedź stwierdzała, że poszukiwania nadal trwają, co pozwalało mieć nadzieję na szczęśliwe odnalezienie bliskich. Czasami wiara w sukces była bezzasadnie podtrzymywana, jak chociażby w przypadku listonosza z Augustowa, który starał się odnaleźć swojego syna. W piśmie od Ambasady Rzeczypospolitej w Moskwie otrzymał informację, iż nazwisko poszukiwanego i innych figurują na liście uwięzionych i internowanych, podlegających ewakuacji ${ }^{43}$. Z biegiem czasu nadzieje słabły, a wraz $\mathrm{z}$ nasilaniem się stalinizmu obława augustowska stała się tematem tabu. Rodziny ofiar dokonywały korekt swoich życiorysów, celem uniknięcia kłopotów i represji. Problemy wynikające z powiązania z wydarzeniami z lipca 1945 r. powstawały w wielu aspektach, od dostępu do pomocy społecznej, pracy czy rekrutacji na studia ${ }^{44}$. W latach 60 . złożonych zostało kilka wniosków o uznanie za zmarłych poszukiwanych osób. Takie prośby były szybko akceptowane, w przeciwieństwie, do opóźnień w odpowiedzi na zapytania ze strony pozostałych rodzin ${ }^{45}$.

Latem 1987 r. nastąpił znaczący przełom w sprawie wyjaśnienia losów ofiar obławy augustowskiej. Po upływie ponad 40 lat przestano uznawać je za zaginione nie wierząc, że ktokolwiek mógłby zostać odnaleziony. 29 czerwca 1987 r. mieszkaniec wsi Dworczysko Stefan Myszczyński odnalazł w okolicznych lasach nieznaną mogiłę ${ }^{46}$. Spowodowało to ogromne poruszenie wśród lokalnej społeczności, wśród której panowało powszechne przekonanie o odnalezieniu miejsca pochówku ofiar obławy augustowskiej. Przeprowadzono ekshumację, podczas której zwrócono uwagę na przeważającą ilość elementów mundurów wojskowych oraz regularne ułożenie ciał w mogile,

${ }^{42}$ Fragment protokołu $\mathrm{nr} 8$ posiedzenia Gminnej Rady Narodowej w Gibach dotyczacy sprawy zwolnienia mieszkańców gminy Giby aresztowanych podczas obławy, [w:] Obława Augustowska - lipiec 1945 r. Wybór źródeł, red. J.J. Milewski, A. Pyżewska, Białystok 2010, s. 129.

${ }^{43}$ Pismo wydziału Konsularnego Ambasady Rzeczypospolitej Polskiej do Michała Olechnowicza w sprawie poszukiwania jego syna Stanisława, [w:] Obława Augustowska - lipiec 1945 r. Wybór źródeł, red. J.J. Milewski, A. Pyżewska, Białystok 2010, s. 202.

${ }_{44}$ J.J. Milewski, Zaginieni w obławie augustowskiej - poszukiwania i pamięć, [w:] Obława augustowska (lipiec 1945 r.), red. J.J. Milewski, A. Pyżewska, Białystok 2005, s. 73.

${ }^{45}$ Pismo naczelnika Wydziału II departamentu II Prokuratury Generalnej w Warszawie do Jadwigi Pietrołaj, [w:] Obława Augustowska - lipiec 1945 r. Wybór źródet, red. J.J. Milewski, A. Pyżewska, Białystok 2010, s. 258.

${ }^{46}$ Śmierć w obławie poniósł ojczym oraz 3 braci Stanisława Myszczyńskiego. Od początku powtarzał, że dokładne usytuowanie grobu pojawiło mu się we śnie. Przypuszcza się, iż przyjął taką wersję z obawy o swoje bezpieczeństwo. 
co mogło wskazywać na złożenie w mogile szczątków żołnierzy niemieckich poległych w walkach toczonych na Suwalszczyźnie latem $1944 \mathrm{r}^{47}$

Obława augustowska była głównym tematem konferencji prasowej rzecznika rządu Jerzego Urbana, która odbyła się 21 lipca 1987 r. Pierwszy głos zabrał kierownik biura Okręgowej Komisji Badania Zbrodni Hitlerowskich w Polsce prokurator Waldemar Monkiewicz. Dziennikarzom zaprezentowano przedmioty znalezione $\mathrm{w}$ rozkopanych grobach. Jerzy Urban w swoim wystąpieniu zarzucił zagranicznym mediom wykreowanie kolejnego pretekstu do pogorszenia relacji polsko - radzieckich, dodając, że

dzisiejsze władze polskie niczego w tej chwili nie wiedzą o tym, aby w przeszłości ktokolwiek w tajemniczy sposób zaginął, nie wiedzą też o tym, aby władze polskie poszukiwały i miały kogo poszukiwać ${ }^{48}$.

Na polecenie Służby Bezpieczeństwa, dyrektor Wydziału Społeczno-Administracyjnego Urzędu Wojewódzkiego w Suwałkach odbył dyskusję ostrzegawczą z trzema założycielami Komitetu. Towarzyszyło temu wydanie 5 września 1987r. decyzji administracyjnej zakazującej jego dalszej działalności. Głównym zarzutem był brak zalegalizowania działań stowarzyszenia oraz fakt, że odpowiedzialność za prowadzenie poszukiwań osób zaginionych należy do kompetencji Polskiego Czerwonego Krzyża i Związku Bojowników o Wolność i Demokrację. Zasugerowano, iż dalsza praca Komitetu może mieć wpływ na zakłócenie spokoju bądź porządku publicznego ${ }^{49}$.

Służba Bezpieczeństwa w Suwałkach opracowując doroczną publikację zawierającą prognozę zagrożeń na 1988 r. oprócz napiętej atmosfery wśród robotników w związku z niezadowoleniem wynikającym z wysokości wynagrodzeń jako główne niebezpieczeństwo uznała kontynuowanie negatywnej działalności przez osoby znane z wrogich postaw wobec aktualnej rzeczywistości w Obywatelskim Komitecie Poszukiwań.

Odkrycie mogił doprowadziło do nagłośnienia tematu obławy augustowskiej. 2 sierpnia 1987 r. utworzono Komitet Poszukiwań Mieszkańców Suwalszczyzny Zaginionych w Lipcu 1945 roku. Kompetencje Komitetu ule-

47 Protokół oględzin szczątków ludzkich w grobach w uroczysku Wielki Bór, [w:] Obława Augustowska - lipiec 1945 r. Wybór źródeł, red. J.J. Milewski, A. Pyżewska, Białystok 2010, s. 260-261.

${ }^{48}$ Stenogram konferencji prasowej dla dziennikarzy zagranicznych rzecznika rządu Jerzego Urbana z 21 lipca 1987 roku, [w:] Obława Augustowska - lipiec 1945 r. Wybór źródet, red. J.J. Milewski, A. Pyżewska, Białystok 2010, s. 265.

${ }^{49}$ Decyzja dyrektora Wydziała Społeczno-Administracyjnego Urzędu Wojewódzkiego w Suwatkach z dnia 5 września 1987 roku zakazująca działalności Obywatelskiemu Komitetowi Poszukiwań Mieszkańców Suwalszczyzny Zaginionych w Lipcu 1945 roku, kopia dokumentu dostępna na stronie internetowej: www.oblawaaugustowska.pl/storage/cms_oblawaaugustowska/files/pismourzedu-wojewodzkiego-w-suwalkach-5-ix-1987.jpg, dostęp: 24.01.2019. 
gały stałemu rozszerzaniu. We współpracy z operatorem filmowym Jackiem Petryckim na zlecenie telewizji BBC powstał film dokumentalny poświęcony obławie o bardzo wymownym tytule - Ale czy o tym wolno mówić? ${ }^{50}$. Komitet nieustannie gromadził materiały dotyczące osób zaginionych latem 1945 r., czego efektem było utworzenie 370 kwestionariuszy osobowych. Środki finansowe do prowadzenia takiej działalności pochodziły z datków sympatyków opozycji, pomocy znanych osób na czele z Prezydentem RP na uchodźctwie Ryszardem Kaczorowskim oraz zagranicznych sponsorów ${ }^{51}$.

27 lutego 1992 r. Prokuratura Wojewódzka w Suwałkach wszczęła śledztwo w sprawie obławy augustowskiej, będąc w posiadaniu kopii dokumentacji zgromadzonej przez Obywatelski Komitet Poszukiwań Zaginionych Mieszkańców Suwalszczyzny w Lipcu 1945 roku. Strona rosyjska odpowiadała na wszelkie zapytania z bardzo dużym opóźnieniem. W odpowiedzi na początku stycznia 1995 r. Ambasada Rzeczypospolitej Polskiej w Moskwie otrzymała pismo z Głównej Prokuratury Wojskowej podległej Prokuraturze Generalnej Federacji Rosyjskiej. Poinformowano w nim, że apel o wyjaśnienie losów obywateli polskich został rozpatrzony ustalając, że operacja wojskowa w lasach augustowskich została przeprowadzona w celu likwidacji formacji wojskowych przejawiających wrogie nastawienie wobec oddziałów radzieckich, z czego wynikały liczne ataki na żołnierzy Armii Czerwonej. Strona rosyjska przyznała się do faktu zatrzymania 592 osób, którego dokonały jednostki 3 Frontu Białoruskiego z udziałem funkcjonariuszy „Smierszu”. Według opisywanego dokumentu wszystkim zatrzymanym udowodniono członkostwo w strukturach Armii Krajowej w latach 1939-1945, co stoi w sprzeczności z faktem, że wśród oskarżonych były osoby dużo poniżej 18 roku życia, kobiety w ciąży, czy starcy. Nie wszczęto wobec nich postępowania karnego, a ich los pozostaje nieznany. Ponadto zauważono, że osoby odpowiedzialne za przebieg operacji nie żyją. Na mocy tych faktów dalsze śledztwo zostało wstrzymane, a strona polska wykazała się biernością i nie zareagowano na przedstawione nowe okoliczności takie jak zupełnie inna liczba ofiar czy daty graniczne przeprowadzenia operacji ${ }^{52}$. Od tego momentu aż do końca lat 90. śledztwo stanęło w martwym punkcie.

Na początku obecnego wieku dokumentację procesową przejął Instytut Pamięci Narodowej, a sprawą zajęła się Oddziałowa Komisja Ścigania Zbrodni

${ }^{50}$ Fragment filmu dostępny na stronie internetowej: www.oblawaaugustowska.pl, dostęp: 11.09.2018.

${ }^{51}$ Szerzej w: A. Maciejowska, Przerwane życiorysy. Obława Augustowska - lipiec 1945 r., Białystok 2010.

${ }^{52}$ Pismo Głównej Prokuratury Wojskowej Federacji Rosyjskiej dotyczące losów osób zaginionych podczas obławy augustowskiej, [w:] Obława Augustowska-lipiec 1945 r. Wybór źródeł, red. J.J. Milewski, A. Pyżewska, Białystok 2010, s. 312-313. 
Przeciwko Narodowi Polskiemu, kontynuując regularne wystosowywanie wniosków do strony rosyjskiej o pomoc prawną. Wiosną $2011 \mathrm{r}$. w Moskwie ukazała się książka Według scenariusza Stalina. Rola organów NKWD-MGB ZSRR w sowietyzacji krajów centralnej i wschodniej Europy w latach 19451953 autorstwa Nikity Pietrowa - rosyjskiego historyka, wiceprzewodniczącego stowarzyszenia „Memoriał”, badającego zbrodnie okresu stalinizmu. Pietrow zauważa, że dokumenty mający bezpośredni związek z obławą augustowską znajdują się w dwóch rosyjskich archiwach: Centralnego Archiwum Ministerstwa Obrony Federacji Rosyjskiej oraz Archiwum Federalnej Służby Bezpieczeństwa ${ }^{53}$. Pierwsze $\mathrm{z}$ nich zawiera pisma obrazujące przygotowania i przebieg samej obławy wraz z nazwiskami osób ją zarządzających. Drugie $\mathrm{z}$ kolei posiada $\mathrm{w}$ swoich zbiorach protokoły zatrzymań, sposoby przesłuchań, a także według przypuszczeń opis mordów ${ }^{54}$.

Największą uwagę w publikacji Pietrowa zwrócił zawarty w niej szyfrotelegram nadany przez Szefa Kontrywywiadu „Smiersz” Wiktora Abakumowa do Ludowego Komisarza Spraw Wewnętrznych Ławrientija Berii. Abakumow melduje o przybyciu na tereny obławy generała majora Gorgonowa wraz z podległym mu oddziałem celem likwidacji bandytów. Towarzyszył mu także generał lejtnant Zielenin, z którym nadał wspólny meldunek do Abakumowa mówiący o zatrzymaniu łącznej liczby 7049 osób, przy czym ponad połowa została zwolniona niezwłocznie po przeprowadzonych rewizjach. Jak wynika z zawiadomienia, na dzień 21 lipca 1945 r. na liście aresztowanych widniały 592 nazwiska ${ }^{55}$. W dalszej części meldunku Abakumow przedstawia Berii propozycję wariantu przeprowadzenia czystki, wyznaczając do jej wykonania oddział „Smiersz” 3 Frontu Białoruskiego, a towarzyszy Gorgonowa i Zielenina rekomenduje jako doświadczonych funkcjonariuszy, którzy wykonają rozkaz z należytą starannością ${ }^{56}$.

Prokurator Zbigniew Kulikowski z białostockiego oddziału Instytutu Pamięci Narodowej uznał moment ukazania się publikacji Nikity Pietrowa jako przełom w śledztwie dotyczącym obławy. Według niego stanowi on potwierdzenie kwalifikacji prawnej tego mordu uznawanej przez stronę polską, jako zbrodni przeciwko ludzkości. Niezwłocznie dokonano uzupełnienia wniosku o pomoc prawną z 2009 r., prosząc o udostępnienie szyfrogramu Abakumowa. Przyjęto także hipotezę istnienia protokołu z dokonania egze-

${ }^{53}$ http://www.dzieje.pl/aktualnosci/nikita-pietrow-fsb-ma-archiwalia-ws-oblawyaugustowskiej, dostęp: 11.09.2018.

${ }^{54}$ Ibidem.

${ }^{55}$ Liczba ta zgadza się z podaną w piśmie Głównej Prokuratury Wojskowej Federacji Rosyjskiej z 4 stycznia 1995 r. W opisywanym meldunku widnieje także zapis o dalszych czynnościach sprawdzających wobec kolejnych 828 osób.

${ }^{56}$ N. Pietrow, op. cit., s. 224-225. 
kucji, który może zawierać dokładne miejsce pochówku ofiar. Prokuratura Generalna Federacji Rosyjskiej w piśmie z 19 lipca 2013 r. odmówiła pozytywnego rozpatrzenia wniosków, powołując się na treść artykułu 2 Europejskiej Konwencji o wzajemnej pomocy w sprawach karnych z dnia 20 kwietnia 1954 r. oraz artykułu 17 umowy z dnia 16 września 1996 r. pomiędzy Polską a Federacją Rosyjską o pomocy prawnej w stosunkach prawnych i cywilnych ${ }^{57}$. Był to ostatni z takich wniosków.

Oddziałowa Komisja Ścigania Zbrodni Przeciwko Narodowi Polskiemu od końca 2013 r. przy pomocy Zakładu Medycyny Sądowej w Białymstoku prowadzi czynności związane z pobraniem materiału genetycznego do badań DNA od członków rodzin ofiar obławy augustowskiej ${ }^{58}$. Ponadto dzięki pomocy Centralnego Archiwum Wojskowego w Rembertowie śledczy dysponują zdjęciami lotniczymi terenów przygranicznych wykonanymi w $1947 \mathrm{r}$. Mają one posłużyć do ewentualnego wytypowania miejsca pochówku ofiar. W lipcu 2014 r. na konferencji naukowej zorganizowanej z okazji kolejnej rocznicy obławy augustowskiej Nikita Pietrow powołując się na relacje świadków tamtych wydarzeń zasugerował miejscowość Kalety w obwodzie grodzieńskim jako potencjalne miejsce kaźni ${ }^{59}$. Argumentował to faktem jej usytuowania w kompleksie leśnym oraz bliską odległością od Gib, gdzie znajdował się ostatni punkt filtracyjny. Niestety, bez zgody władz białoruskich jakiekolwiek prace poszukiwawcze nie mogą zostać przeprowadzone. Równocześnie oprócz czynności poszukiwawczych Oddziałowa Komisja Ścigania Zbrodni Przeciwko Narodowi Polskiemu prowadzi przesłuchania świadków, których ilość na chwilę obecną szacuje się na około 700 osób.

\section{Podsumowanie}

Zagadka obławy augustowskiej po ponad 70 latach od jej przeprowadzenia pozostaje $w$ dalszym ciągu bez wyjaśnienia. Trudno uwierzyć, że takie wydarzenia mogły mieć miejsce w czasie względnego pokoju. W przedstawionym opisie obławy widać, że nie była to przypadkowa i spontaniczna operacja. Podziemie niepodległościowe było główną przeszkodą Rosjan do swobodnej organizacji aparatu państwowego na terenie powiatów suwalskiego i augustowskiego. Nie mniej wśród ofiar były kobiety i dzieci, co nie znajduje logicznego wytłumaczenia. Porównania i analogie do zbrodni

57 https://bialystok.wyborcza.pl/bialystok/1,35241,14398863,0blawa_Augustowska_ Rosja_nie_pomoze__Rodziny_walcza.html, dostęp: 11.09.2018.

${ }^{58}$ http://www.oblawaaugustowska.pl/sledztwo-ipn/, dostęp: 11.09.2018.

59 Świadkowie podawali przybliżony czas, jaki mijał od wyjazdu ciężarówki z więźniami do jej powrotu bez nich. Eksperymenty i oględziny dróg wyjazdowych z Gib potwierdziły taką wersję. 
katyńskiej nie są przypadkowe, jednak rodziny żołnierzy zamordowanych w 1940 r. od dawna znają miejsca ich pochówku, w przeciwieństwie do bliskich ofiar z lipca $1945 \mathrm{r}$.

Przez wszystkie lata panowania ustroju komunistycznego w Polsce rodziny były osamotnione w swoim dążeniu do poznania prawdy. Wszelkie odpowiedzi na kierowane przez nich pisma do wielu instytucji, w tym międzynarodowych, były odmowne i wymijające. Prowadzenie poszukiwań na własną rękę niosło za sobą olbrzymie ryzyko i utrudnienia w niemal każdym aspekcie codziennego życia. Państwo dążyło do zatarcia prawdy o tragicznych wydarzeniach z lipca 1945 r. Dopiero po przemianach ustrojowych śledztwo wkroczyło na właściwe tory. Mimo to trudno będzie je ostatecznie zakończyć w niedalekiej przyszłości.

Rzeczą niezwykle trudną jest jednoznacznie określenie kwalifikacji prawnej obławy augustowskiej, gdyż spełnia ona warunki przytoczone w definicjach zarówno zbrodni wojennej, zbrodni przeciwko ludzkości, jak i zbrodni komunistycznej. Aktualne najczęściej uznaje się ją za zbrodnię przeciwko ludzkości.

Z przeprowadzonych badań wynika, że wszelkie niezbędne dokumenty pozwalające odnaleźć groby zamordowanych oraz ustalić winę za popełnienie tego czynu znajdują się na terenie Federacji Rosyjskiej. Równie wielce prawdopodobne jest to, że same mogiły nie są zlokalizowane na terenie Polski. Wszystkie prośby o pomoc prawną spotkały się z odpowiedziami odmownymi. Ponadto osoby fizyczne, które mogły dopuścić się tych morderstw od dawna nie żyją, a międzynarodowe instytucje i trybunały posiadają zdolności do osądzenia wyłącznie państw jako podmiotów prawa międzynarodowego.

Strona polska stara się do końca wykorzystać możliwość prowadzenia dochodzenia na terenie kraju. Wraz z rozwojem techniki działania te stają się coraz bardziej rozwinięte. Przykładem może być analiza zdjęć lotniczych $\mathrm{z}$ archiwum w Rembertowie, czy zapoczątkowane przed kilku laty pobieranie materiału genetycznego, celem porównania go ze szczątkami, gdy takowe uda się odnaleźć.

Badacze i historycy zajmujący się obławą augustowską są przekonani, że bez decyzji politycznej Rosja nie udzieli pomocy prawnej w śledztwie. Oprócz badań IPN przy pomocy rodzin organizuje wiele wydarzeń mających podtrzymać pamięć o ofiarach. Do takowych należy zaliczyć chociażby konferencje naukowe czy wystawy organizowane na terenie całego kraju. Przedmiot badań historycznych dotyczących obławy z całą pewnością nie został wyczerpany, czego dowodem jest wydana w 2017 r. publikacja autorstwa Tadeusza Radziwonowicza i Barbary Bojaryn-Kazberuk pt. Obława augu- 
stowska 1945 okoliczności i ofiary w dokumentach archiwalnych. Jej wydawcą jest Archiwum Państwowe w Suwałkach.

Od kilku lat na mocy uchwały Sejmu dzień 12 lipca obchodzony jest jako Dzień Pamięci o Ofiarach Obławy Augustowskiej. Niewątpliwie należy taką inicjatywę docenić, jednakże władze centralne muszą dojść jak najszybciej do wniosku, że nie o takie decyzje polityczne chodzi. Istnieje bowiem zagrożenie, że obława augustowska zostanie całkowicie zapomniana. Tylko dzięki niewielkiej grupie ludzi jej pamięć o niej pozostaje wciąż żywa, a czynności dochodzeniowo - śledcze nie zostały zaprzestane. Daje to powody, aby mieć znikomą nadzieję na wyjaśnienie tej zbrodni.

\section{BIBLIOGRAFIA}

\section{Opracowania}

Awchimowicz N., Mój Augustów, [w:] Europa nieprowincjonalna. Przemiany na ziemiach wschodnich dawnej Rzeczypospolitej (Białoruś, Litwa, Łotwa, Ukraina, wschodnie pogranicze III Rzeczypospolitej Polskiej) w latach 1772-1999, red. K. Jasiewicz, Warszawa 1999, s. 692-695.

Dzierżanowski M., Blinkiewicz A., W służbie Moskwy, „Tygodnik Wprost” 2005, nr 28 (1180). Krajewski K., Łabuszewski T., Białostocki Okręg AK-AKO: VII 1944 - VIII 1945, Warszawa 1997. Kulikowski S., Sewastianowicz I., Nie tylko Katyń, Białystok 1990.

Maciejowska A., Przerwane życiorysy. Obława Augustowska - lipiec 1945 r., Białystok 2010.

Milewski J.J., Pyżewska A., Obława Augustowska - lipiec 1945 r. Wybór źródeł, Białystok 2010.

Milewski J.J., Pyżewska A., Obława augustowska (lipiec 1945 r.), Białystok 2005.

Pawluczyk J., Cierniowa droga do wolności. Wspomnienia żołnierza AK z okresu okupacji niemieckiej, sowieckiej i z czasów PRL-u, Białystok 2005.

Pietrow N., Psy Stalina, Warszawa 2012.

Roman W., Działalność wojsk NKWD przeciwko polskiemu podziemiu w świetle dokumentów sowieckich, [w:] Zbrodnie NKWD na obszarze województw wschodnich Rzeczypospolitej Polskiej, red. B. Polak, Koszalin 1995.

Strzembosz T., Konspiracja na ziemi augustowskiej pod okupacją radzieckq (1939-1941), „Przegląd Historyczny” 1992, z. 4, s. 667-705.

Szlaszyński J., Dzieje lipcowej obławy 1945 r., „Przegląd Augustowski” 1996, nr 5.

Szlaszyński J., Makowski A., Augustów. Monografia historyczna, Augustów 2007.

\section{Źródła internetowe}

https://bialystok.wyborcza.pl/bialystok/1,35241,14398863,Oblawa_Augustowska_Rosja_ nie_pomoze_Rodziny_walcza.html 
www.dzieje.pl/aktualnosci/nikita-pietrow-fsb-ma-archiwalia-ws-oblawy-augustowskiej www.naszdziennik.pl/mysl/57837,sladami-oblawy.html

www.oblawaaugustowska.pl

www.oblawaaugustowska.pl/storage/cms_oblawaaugustowska/files/pismo-urzedu-wojewodzkiego-w-suwalkach-5-ix-1987.jpg

\section{Akty prawa wewnętrznego}

Kodeks karny ZSRR z dnia 1 stycznia 1927 r.

Rozporządzenie Prezydenta Rzeczypospolitej z dnia 11 lipca 1932 r. - Kodeks karny.

Ustawa z dnia 19 kwietnia 1969 r. Kodeks karny.

Ustawa z dnia 6 czerwca 1997 r. Kodeks karny.

Ustawa z dnia 18 grudnia 1998 roku o Instytucie Pamięci Narodowej - Komisji Ścigania Zbrodni przeciwko Narodowi Polskiemu

\section{Umowy międzynarodowe}

Konwencja dotycząca praw i zwyczajów wojny lądowej (IV konwencja haska) (Haga, 18.10. 1907 r.).

Traktat Wersalski z 28.06.1919 r.

Konwencja Genewska o polepszeniu losu chorych i rannych w armiach czynnych (Genewa, 27.07.1929 r.).

Karta Międzynarodowego Trybunału Wojskowego (Londyn, 8.08.1945 r.)

Konwencja o traktowaniu jeńców wojennych (Genewa, 12.08.1949 r.)

Konwencja o ochronie osób cywilnych podczas wojny (Genewa, 12.08.1949 r.)

Konwencja o Ochronie Praw Człowieka i Podstawowych Wolności (Rzym, 4.11.1950 r.)

Umowa o pomocy prawnej i stosunkach prawniczych w sprawach cywilnych, rodzinnych i karnych między Polską Rzeczypospolitą Ludową a Związkiem Socjalistycznych Republik Radzieckich z dnia 20 grudnia $1957 \mathrm{r}$.

Konwencja o niestosowaniu przedawnienia wobec zbrodni wojennych i zbrodni przeciw ludzkości (Nowy Jork, 26.11.1968 r.)

Statut Międzynarodowego Trybunału Karnego (Rzym, 17.07.1998 r.)

Patryk Basinski

\section{AUGUSTOW CHASE AS THE LARGEST UNSETTLED CRIME COMMITTED ON POLES AFTER WORLD WAR II}

$\mathrm{T}$

he article describes the Augustow chase, the largest crime on Poles after World War II, carried out in July 1945 in the lands of Suwalki and Augustow. As a result, almost 600 people was died, mainly civilians. The aim of the article was to analyze legal and practi- 
cal obstacles in the pursuit of the Polish side to account for the so Augustow chase. The research problem was the answer to the question of whether there are real chances of obtaining redress from the Russian side for the events of the Augustow chase on the way of domestic and international court procedures. The author presented the genesis, course and effects of the raid. Then he made an attempt was made to qualify the crime and the current state of the investigation was presented.

Keywords: Augustow, Chase, July 1945, Small Katyn. 